\title{
ISLAMIC EDUCATIONAL VALUES IN 29 JUZ HARGA WANITA NOVEL BY MA'MUN AFFANY
}

\author{
Yeny Saswita \\ yenyridwan@gmail.com
}

\begin{abstract}
This study aims to describe and analyze the existing religious messages in a $29 \mathrm{Juz}$ Harga Wanita novel, which is about the value of Islamic Education in Novel by Ma'mun Affany. The method used in this study is interpretive research, i.e. research that performs analysis to get the meaning of a phenomenon and aims to gain a deep understanding, especially the value of Islamic education and its relevance in novel 29 Juz Harga Wanita by Ma'mun Affany. This study focuses on literature review, which is utilizing the source library to obtain research data without doing field research. Make the novel as an educational medium by taking lessons from the messages contained therein. The data are grouped into three kinds, namely (1) the data of the faith value in the $29 \mathrm{Juz}$ Harga Wanita novel which includes (a) faith in God; (b) faith in the books of God; (c) faith in qada and qadar, (2) data of religious devotion values in 29 Juz Harga Wanita novel that includes (a) Istiqomah (sticking to religion) (b) Ikhtiar (try and pray); (c) obey the prayer; (d) tawaadlu (humble/not arrogant); (e) qona'ah (willing and sufficient for all that is owned); and 3) data of noble values in 29 Juz Harga Wanita novel which includes: (a) nobility to Allah, (b) noble character to man that is to self, family, neighbor, society; and (c) nobility to the environment. As rahmatan lil Alamin, Islam placed women in a glorious place. Islam is a religion that respects and appreciates women and men to God in absolute terms. There is relevance between the values of Islamic Religious Education in 29 Juz Harga Wanita novel, with the goal of Islamic religious education that is to invite humans to do good and avoid bad nature in accordance with the norms that have been established by Islam. Islam has given a clear concept about the procedure or process of a marriage based on the Qur'an and the Sunnah as-saheeh.
\end{abstract}

Keywords: Value of Islamic Education, 29 Juz Harga Wanita Novel, Ma'mun Affany

\section{A. Introduction}

Being beautiful in the eyes of men of love for what is desired: women, children, wealth of gold, silver, selection horses, livestock animals and fields. That is the joy of life in the world, and in the sight of Allah is a good place of return (heaven). (QS. Ali Imran: 14).

Education is an integral part of the process of human creation. In order to understand the nature of education it requires an understanding of human nature. ${ }^{1}$ Humans beings are special that Allah created with a variety of potential, and the potentials can be developed optimally with education. Education is a conscious effort undertaken by family, community and

\footnotetext{
1 Muhaimin, Paradikma Pendidikan Islam :Upaya Mengefektifkan Pendidikan Agama Islam di Sekolah (Bandung : PT. Remaja Rosdakarya, 2004), 27.
}

government, through counseling, teaching and/or training activities, which take place in school and out of school throughout life, to prepare learners to play a role in various environments appropriately in the future. ${ }^{2}$ Education is a basic necessity for human beings because when someone born he/she did not know anything as the word of God in the Qur'an, the following; which means more or less: "and Allah expels you out of your mother's belly, does not know anything" (QS Al Mujadalah: 2).

Nowadays, there are many teenagers fall into the valley of sorrow in the name of love. Their feelings have been tainted by heretical thoughts that only concern the physical and the pleasures of being born.

\footnotetext{
${ }^{2}$ Redja Mudyaharjo, Pengantar Pendidikan :Sebuah Studi Awal Tentang Dasar-Dasar Pendidikan pada Umumnya dan Pendidikan di Indonesia (Jakarta : PT. Raja Grafindo Persada, 2010), 11.
} 
They are completely neglectful of moral values, morals and virtues. Such moral degradation is more worrying, because not only affects the adults but also has happened to the young shoots students who are expected to continue the struggle of future generations.

Faced with the phenomenon, allegations are often directed to education as the cause. The moral crisis decline that is now facing the world of education is really tarnished it faces and that seemed only helplessness mere. This is understandable, because education is the front guard in preparing quality of human resources and morally. The main goal of education is to produce human personalities that are mature intellectually, emotionally and spiritually.

Islamic educational values are important and useful concepts and ideals for human beings. Education will be completed if their child has reached the age of adulthood, ready to marry and able to be independent, after mastering a number of practical skills in accordance with the demands and needs of life in the community environment. ${ }^{3}$ This value and virtue must be the basis for the development of human life that has civilization, goodness, and happiness individually and socially. ${ }^{4}$ The higher a person's morality means the more qualified one's faith is the other way around. Islam encourages its people to have the values of akhlaqul karimah by referring to Rasulullah SAW. In the relation to education that is as an effort to develop character or moral.

Harmonious life is necessary, first reason, man is naturally a creature with a

\footnotetext{
${ }^{3}$ Ramayulis, Ilmu Pendidikan Islam, (Jakarta :

Kalam Mulia, 2002), 29.

${ }^{4}$ R. Mulyana, Mengartikulasikan Pendidikan Nilai, (Bandung : Alfabeta, 2004), 106.

5 Zainal Arifin, dkk, Moralitas Al-Qur'an dan Tantangan Modernitas; Telaah Atas Pemikiran Fazlur
}

unique position. This uniqueness lies in its duality of morality. On the one hand, human beings are willing to do things that are good, integrative and positive, such as helping others, being patient and so on. On the other hand, humans have a tendency toward bad, negative and disintegrative things, such as anger, rough and so forth.

This situation is the eternal challenge of man and who make his life as an effort to fight for noble character and praiseworthy. Second, human life is plural, both in terms of ethnicity, culture, language, race and mindset and action. Pluralism is real. The phenomenon of pluralism in certain situations can cause conflict. Therefore, conflict can be avoided if morality is a reflection of the value of Islamic education can be enforced. ${ }^{5}$

According to Ahmad Tafsir, "in the Science of Islamic Education at least it can provide theory about education in household, education in society and education in school. While the implementation of education is in accordance with what is contained in terms Ta'lim, ta'dib and Tarbiyah". ${ }^{6}$

Islamic education is oriented on two lives that is worldly and ukhrowi. In Islam life in the Hereafter is a continuation of life in the world, even a quality of life in the Hereafter is the consequences of life in the world. All the actions of Muslims in any activity have a connection with the afterlife. Islam is very universal contains teachings that can guide people to the happiness of life in the world and hereafter. Allah SWT said that "and look for what Allah has granted to you the happiness of the Hereafter and do

Rohman, Al Ghazali dan Ismail Rajial-Faruqi (Yogyakarta : Gama Media, 2002), 1-2.

${ }^{6}$ Ramayulis, Ilmu Pendidikan Islam (Jakarta : Kalam Mulia, 2002), 39. 
not forget the happiness and enjoyment of the world ..." (QS Al Qashas: 77)

For this Islam teaches its people to always establish a close relationship with Allah SWT (Hablum minnallah) and relationships with fellow human beings (hablum minannas).

Based on this background, the author looks for Islamic educational values contained in the novel $29 \mathrm{Juz}$ Harga Wanita, in the hope to be a guide for young Muslim, in choosing a life partner in accordance with the values of Islamic education based on Al Quran and hadith shahih. Stories in novel $29 \mathrm{Juz}$ Harga Wanita teaches a lot especially about the virtues of the teachings of $A l$ Quran and $A l$ Sunnah that are applied by his character. Here, especially the female characters (Naela Khasna).

The figure of women who inspire many other Muslim women to wear veil and become solekhah, the reader will not realize the gentle and meaningful advice because it drifts into the beautiful plot of the story. Obviously this novel represents a woman's feelings. Naela Khasna's Character: firm stance, faithful, patient, sholehah, gentle, tawadlu, istiqomah. All difficulties in her life always be propped up and surrendered to God Almighty, because she realized that God is entitled to the whole story of her life path. The firmness, confidence and loyalty of her love story are entrusted to the destiny of Allah SWT which will surely meet with her true love that was lost. Because the character is convinced by faith in the Destiny of Allah SWT her soul mate would not be confused.

Disclosure of Islamic education values contained in novel $29 \mathrm{Juz} \mathrm{Harga}$ Wanita is the main purpose of the author in this Thesis. However, there is not author who study specifically addresses the theme in the form of articles, theses and thesis. Based on the above explanation, the writer considers that it is necessary to study more deeply about Islamic Values of Education in Novel 29 Juz Harga Wanita by Ma'mun Affany.

\section{B. Research Methods}

The method used in this study is interpretive research, i.e. research that performs analysis to get the meaning of a phenomenon and aims to gain a deep understanding, especially the value of Islamic education and its relevance in novel 29 Juz Harga Wanita by Ma'mun Affany.

Data are grouped into three kinds, i.e.

1) The data of faith value in novel $29 \mathrm{Juz}$

Harga Wanita which includes

a. believe in Allah;

b. faith in the books of God;

c. faith to qada and qadar,

2) Data of devotion values of worship in novel 29 Juz Harga Wanita that is covering

a. Istiqomah (sticking to religion)

b. Ikhtiar (try and pray);

c. Praying the prayer;

d. Tawaadlu (humble/not arrogant);

e. qona'ah (willing and sufficient for all that is owned); and

3) Data of noble character values in novel 29 Juz Harga Wanita which includes:

a. noble deity to God,

b. nobility to humankind is to oneself, family, neighbor, society; and

c. Morality to the environment.

Type of research conducted by the writer is a qualitative research, i.e. research methods that tend to describe a single variable, the focus of the problem is what is the problem, why continue the problem occurs in these aspects and ended with questioning how the solution or the 
problem. ${ }^{7}$ While the research type is research library, the method of collecting data by finding information through books, magazines, newspapers, and other literature that aims to form a theoretical basis.

In the method of analyzing the data, the writer uses descriptive qualitative methods and Library Research (bibliography research) and an interview via Email of Novel 29 Juz Harga Wanita writer is by Ma'mun Affany. It tends to describe a single variable, such as the story in research by the writer in her Thesis "Value of Education in Novel 29 Juz Harga Wanita". Formulation or focus of the problem, beginning with Islamic Education Value contained in the content of the story Novel 29 Juz Harga Wanita. It can be seen in the title, that the only variable is the value of Islamic education, there is nothing else, so the study of her theory is focused only in that issue. While the research objects is novel 29 Juz Harga Wanita and to support the theoretical foundation on the value of Islamic education contained in Novel $29 \mathrm{Juz}$ Harga Wanita, the writer uses the method of library research.

\section{Discussion and Research Results 1. Understanding Values}

Values can also be interpreted as conceptions in people and society about things that are considered good, right, badwrong. ${ }^{8}$ The globalization era, today, greatly affects the values of socio-cultural development of Indonesian Muslim society in general, or Islamic education in particular.

follows:

The properties of Values are as

1) The value is a reality and exists in human life that cannot be felt because it is abstract but it can be observed through

\footnotetext{
${ }^{7}$ Imam bawani, Metodologi Penelitian Pendidikan Islam, ( Sidoarjo: Khasanah Ilmu Sidoarjo, 2016 ), 108.
}

the object of value. The example of the object is honesty.

2) Value has a normative nature, which means it contains ideals and expectations. Norms can be foundation in this value. The example is justice value.

3) Value serves as a supporter who is believed to be a motivator for humans in performing an action. For example is the value of piety.

There are three kinds of values in philosophy namely;

a. Logic values are true and false values

b. Aesthetic value is a wonderful value and not beautiful.

c. Ethical or moral values are good or bad.

The example of the logic value is when a student answered the question correctly then he is logically correct, but if there is a student that gave wrong answer it does not mean that he is bad because the answer is wrong, because bad is a moral value. An example of aesthetic value is when one saw a scene or painting he can feel the beauty in it but if seen by others it does not mean the same. Value or beauty cannot be imposed. Moral value is the value that handles the actions or behavior of people in everyday life related to morals, and good or bad behavior.

Value in Islamic Education

In the Qur'an, the normative value consists of 3 main pillars, namely;

1. I'tiqadiyyah, it aims to organize individual beliefs related to the education of faith, such as the six pillars of faith, namely faith in Allah SWT, faith in angels, faith in the books, faith to the apostle, faith to the day of judgments and faith to qadha and qadhar.

2. Khuluqiyah, it aims to decorate themselves with good morals and

\footnotetext{
${ }^{8}$ Muhaimin dan Abdul Mujib, Pemikiran Pendidikan Islam ( Bandung: Trigenda, 1993), 110.
} 
cleanse themselves of disgraceful morals related to ethics education.

3. Amaliyah, the value associated with muamallah education and religious education as well as relating to the education of everyday behavior.

\section{Understanding Education}

Science and Education are like two sides of a coin that are both inseparable. Science is the main object in education. Whereas education is a process in transferring knowledge which is generally done in three ways, namely; oral, written or drawing and deeds or behavior/attitude. ${ }^{9}$

The word education literally comes from the word "pedagogy" i.e. "paid" meaning child and "agogos" which means to guide, so pedagogy is the science in guiding the child. While the term definition of education is a process of changing attitudes and behaviors of a person or group in an effort to mature humans or learners through the efforts of teaching and training.

There are also 3 points of place of education, namely;

1. In the household

2. In the community

3. At school.

\section{Understanding Islamic Education}

Islamic educational science is the science of education based on Islam. Islam is a religion brought by Prophet Muhammad SAW. Islam is a set of teachings about human life; the teaching is formulated based on and derived from the Qur'an and Hadith and mind. ${ }^{10}$ The used of this basic should be in a right order; Al Quran is the first, if there

\footnotetext{
${ }^{9}$ Heri jauhari Muchtar, Fikih Pendidikan ( Bandung: PT Remaja Rosdakarya, 2008 ), 12.

${ }^{10}$ Ahmad Tafsir, Ilmu Pendidikan Islam ( Bandung: PT Remaja Rosdakarya,2015), 18.

${ }^{11}$ Ramayulis, Metodologi Pengajaran Agama Islam ( Jakarta: Kalam Mulia, 2001), 3.

${ }^{12}$ Nazarudin Rahman, Manajemen Pembelajaran; Implementasi Konsep, Karakteristik dan Metodologi
}

is no further clarity then use Hadist, if there is no then just use the mind. Science and Education are like two sides of a coin that are both inseparable. Science is the main object in education. While education is a process in transferring the knowledge which is generally done in three ways, namely; oral, written or drawing and deeds or behavior/attitude. Education comes from the word didik. Given the prefix of pend and the end kan, which means the actions, things, and ways. Religious education in English is known as religion education, which is defined as an activity that aims to produce religious people. Religious education is not only provides knowledge about religion, but more emphasis on feeling, attitude, personal ideals, trust activities. $^{11}$

Thus, the Islamic Religious Education in schools is directed to increase the belief, understanding, appreciation, and practice of Islamic teachings. Nazarudin Rahman explained that there are some things that need to be considered in learning Islamic religious education, namely as follows: ${ }^{12}$

Islamic education is defined as: (1) Islamic religious education as school subjects in schools that is managed under the Ministry of National Education and Culture; (2) Islamic Schools in the form of Madrasah and Islamic University are managed under the Ministry of Religious Affairs; and (3) Traditional Islamic Schools in the form of Pesantren is managed under the coordination of the Ministry of Religious Affairs. ${ }^{13}$ Characteristic of Islamic Education is;

\footnotetext{
Pendidikan Agama Islam di Sekolah Umum ( Yogyakarta: Pustaka Felicha, 2009 ), 12.

${ }^{13}$ Mochammad Tolchah, The Political Dimension of Indonesian Islamic Education in The Post-1998 Reform Period ( Jurnal Islam Indonesia, Vol. 8 Nomor 02. Desember 2014 ),289.
} 
1. The first characteristic; there is an emphasis on Islamic education for the search of science, mastery and development on the basis of worship of Allah SWT.

2. The second characteristic; recognition of one's potential and ability to develop.

3. The third characteristic; the practice of knowledge on the basis of responsibility to God and human society.

Islamic Religious Education (PAI) as a conscious effort, which is a guiding activity, teaching and/or exercises conducted in a planned and conscious of the goals to be achieved.

a. Learners should be prepared to achieve the goal of Islamic Religious Education.

b. Educators or Islamic Religious Teachers (GPAI) should be prepared to be able to carry out their duties, namely planning guidance, teaching and training.

c. Islamic religious education activities are directed to improve the belief, understanding, appreciation, and practice of Islamic teachings.

In terms of its objectives, Islamic Education is divided into 2, namely;

1. Islamic Education in General

It can be interpreted as an effort to construct and develop human potential optimally according to its status, based on the syariat of Islam conveyed by Prophet Muhammad SAW, so that humans can act as devoted devotees of Allah SWT with all of activities in order to create an ideal condition of Islamic life, safe, prosperous and qualified, and obtain the guarantee of the hereafter.

2. Special Islamic Education

The efforts to guide and develop human potential either individually or in groups which are carried out in stages according to their growth and development, gender, talents, intelligence level and spiritual potential of each maximally.

\section{The Basis and Objectives of Islamic Religious Education}

a. Understanding the Basic of Islamic Education

Because Education occupies the most important position in human life, it is natural for Muslims to place the Quran, hadith and mind as the basis for his educational theories. That is why Islamic Education chooses Al Quran and hadith as its basis. Why Muslims put Al Quran and hadith into the foundation of their education, the answer is that both sources are guaranteed the truth. Why Muslims do not take philosophical theories such as liberalism, pragmatism, and materialism as the basis of education, the answer is because the -isms are man-made, and therefore it cannot be guaranteed the truth.

b. The purpose of Islamic Education

There are 4 Objectives of Islamic

Education, namely:

1) General purpose

The objective that will be achieved with all educational activities is either by teaching or by other means. The general objectives should be linked also to the national educational objectives of the country where the Islamic education is and should be in synergy with the institutional goals of the institution that carries out the education.

2) Final destination

Islamic education lasts for life, then, the ultimate goal is at the time of life in this world has ended too. The general purpose of being human beings with the pattern of devotion can change up and down, increased and decreased in the course of someone's life. Feeling and environmental experiences can influence it.

\section{3) Temporary Purpose}

A temporary purpose is the goal to be achieved once the students are given a 
certain amount of experience which is planned in a formal education curriculum. At the temporary goal of the insan kamil (good man) form with the pattern of piety is already visible even in the simple size, at least some of the basic features are already visible in the students' personal.

4) Operational Purpose

The operational objectives are the practical goals to be achieved with certain educational activities. In this operational purpose more demanded of the students' ability and skill. The operational nature is more highlighted from the nature of appreciation and personality. Abilities and skills demanded in the students, which is part of the ability and insan kamil skill in the size of the child, which leads to the form of insan kamil to be more perfect (increasing). Children can already perform worship, at least obligatory worship, although he has not understood and lived the worship.

\section{Relevance of Research Results with Islamic Education}

After reading, studying, researching, understanding and analyzing novel 29 Juz Harga Wanita, the writer found some kind of Relevance Value of Islamic Education in Novel 29 Juz Harga Wanita and the value of Islamic Education is clearly described in every series of stories in the novel. The Value of Islamic Education is about Aqidah (belief) Education, Sharia (worship), and Akhlak (character) and there is the guidance of the letter of the Qur'an as its foundation.

a. The Value of Aqidah (Faith) Education

1) Faith in Allah SWT

This is evidenced by the faith of Toni Saputra who was neglected before getting to know the figure of Naela Khasna. It is due to his arid life, and untouched by a mother's love since he was childhood. It is added by the figure of a father who is very indifferent to him. His wish is a father who always reminds of the obligation of a Muslim to worship Allah SWT. But the facts say another, every time their communication is just a splash of cold water in the morning and a hard slap cheeps if Toni asks about her mother figure.

2) Faith to the Angel

"You are all-knowing, You are allHearer, You must be in every prayer ...". The above prayer is an honest, sincere plea of a Toni who is witnessed by the angels who come to pray for the request to be granted.

3) Faith in the Book

Al-Quran is revealed so that people can take lessons in it, by reading, interpreting, and most important is to live it in life.

4) Faith to the Prophet

A Muslim is also obliged to justify all the prophets with their properties, advantages and privileges. Through his struggle to inculcate the Divine message, man will experience salvation in his life. They sincerely remind people, guiding people to the right path. They are only carrying out the task of connecting human life with Allah's guidance. If the Prophet is a protector who saves and works selflessly, then as the actualization of faith in him, man should follow his call, keep his teachings.

5) Faith to the Day of Judgment

With such beliefs that make a special wisdom for a believer that life in this world is not just looking for the provision of life in the world, but clearly a Muslim must also find provisions to live in the afterlife. And the coming of the Day of Resurrection is the beginning of the beginning of life in the Hereafter.

6) Faith to Qadha and Qadar

Destiny is Allah's provision over His servants in Islam occupies a central position because it belongs to one of the pillars of faith. But nevertheless it does not 
necessarily imply a mere negative aspect of that belief, that it is of no use to try and work hard that have all been determined. The mystery of destiny precisely brings the message that man must keep trying, because we do not know how our destiny is the most important is the end result which is handed over to God.

b. The Value of Islamic Education (Worship)

1) The command to perform the prayer Prayer is the second pillar of faith after the creed. As a good believer of course we must perform prayers on time.

2) The command requires knowledge Demanding knowledge is an obligation for every Muslim. This is because science is the most essential thing in human life. Islam is a religion that puts the learned man on a high level. This directly indicates that Islam wants its people to be active in studying. God will raise the degree of the knowledgeable.

3) Command of sincere charity

Sincere here is the desire of Allah with a charity, clean it from all individual and worldly stains. Nothing is Background of a charity except for Allah SWT. Sincere is one of many charities, even in the beginner's line of charity. Because the receipt of various charities cannot be perfect except with sincerity.

\section{4) Dzikir to Allah SWT}

Dhikir in Islam is defined as a human effort to remember the power and majesty of Allah SWT by bringing his heart to His heart. Dhikir is remembering the favors of Allah or calling the pronunciation of the word Allah SWT, bertasbih (use rosary), bertahmid, and bertahlil.

5) Pray to Allah SWT

Islam advocates that every matter that we are not able to overcome it then we should ask God only for help. By praying will bring pleasure, serenity and tranquility.
Prayer is a lamp and a mover of worship. Prayer is an expression of our sense of helplessness as a servant before God as well as the way we present Him in our lives. God commands people to always pray to God.

c. Value of Morals Education

1) Moral to self

a) Forbearance: In times of difficulties befalling a person, then only steadfastness is able to illuminate the heart to keep from despair so as to be able to save him from discouragement. In the face of this life, God always gives a trial to man whether in the form of pleasure, comfort, or trials in the form of suffering. Patience is needed by every person. Patience is a form of prudence in order not to be too happy and out of control.

b) Taubat: When a person has committed a sin or immoral, he must immediately ask forgiveness of God, regretting his actions and promising not to repeat them again. A noble man does not let himself be drowned in sin and wrong.

2) Morals against parents

a) Disobedient prohibition against parents: and your Lord has commanded that you should not worship other than Him and should do good thing to mothers and fathers. If one of them until his/her old age is in your care, then do not say "ah" and do not yell at them both, and speak to both good words. (al-Isra verse 23).

b) Worship to the parents: and we command the people (to do good thing) to both parents. Her/his mother has conceived her/him in a state of increasing weakness, and weaned her/him at the age of 2 years, give thanks to Me and to your parents. Just to Me on your return. (al-Luqman 13)

c) Tawadlu: and do not turn away your face from men (because of arrogance) 
and do not walk on earth arrogantly. Really God does not like the people who are arrogant and pride. (alLuqman verse 18)

d) Qonaah: and obey Allah and His messenger and do not quarrel which causes the trembling and your power to be lost and be patient, God Almighty with those who are patient. (al-Anfal verse 46)

e) Istiqomah: then you are (Muhammad) (in the right way) as has been commanded to you and also the one who repents with you, and do not transgress. Really, He is good at what you do. (al-Hud verse 112)

\section{3) Morals against the family}

"And those who say, our Lord, bestow on us our spouses and our descendants as our hearts, and make us leaders for those who fear. (al-Furqon verse 74)

4) Morals against Brothers

"Indeed, the believers are brothers, therefore reconcile between your two brothers (disputants) and pious to Allah SWT that you may gain mercy. (al-Hujurat verse 10)

5) Morals against others

"Indeed Allah SWT is not reluctant to make a mosquito or a smaller than that as a parable. As for those who believe, they know that it is the truth of God. But those who disbelieve say, "what does Allah mean by this parable?". By that (parable) there are many people that He has left astray, and with it many are guided. But there is no one who misguided by Him with (the parable) except those the wicked. (al-Baqarah verse 26)

\section{Conclusions}

From the research that has been done, the writer can take some conclusion as follows:
1. Novel 29 Juz Harga Wanita is, Novel which has religious value (Islamic Religion) that is aspect of Aqidah Education (faith) include faith to God, faith to angel, faith to book, faith to prophet, and faith to destiny. The aspects of Sharia Education (worship) include the command of prayer, study, charity sincerely, zikir and pray to God. While the aspect of education of morals (character) include morals to self (patience, repentance, optimism, trust, thankfulness, accept hidayah and avoid anger), morals against parents (prohibition of ungodly against both parents and devoted to both old people), morals towards the family, morals toward brother, morals against others (greeting and help).

2. Relevance between the values of Islamic Education in novel 29 Juz Harga Wanita with the goal of Islamic religious education is equally invites people to hinder bad characteristics in accordance with the norms set by Islam. The novel is also relevant to religious education materials.

\section{References}

Arifin, Zainal, et.al. 2002. Moralitas AlQur'an dan Tantangan Modernitas; Telaah Atas Pemikiran Fazlur Rohman, Al Ghazali dan Ismail RajialFaruqi, Yogyakarta: Gama Media.

Bawani, Imam. 2016. Metodologi Penelitian Pendidikan Islam. Sidoarjo: Khasanah Ilmu Sidoarjo.

Muchtar, Heri Jauhari. 2008. Fikih Pendidikan. Bandung: PT Remaja Rosdakarya.

Mudyaharjo, Redja. 2010. Pengantar Pendidikan :Sebuah Studi Awal Tentang Dasar-Dasar Pendidikan pada Umumnya dan Pendidikan di Indonesia. Jakarta: PT. Raja Grafindo Persada. 
Muhaimin. 2004. Paradikma Pendidikan Islam :Upaya Mengefektifkan Pendidikan Agama Islam di Sekolah. Bandung: PT. Remaja Rosdakarya.

Muhaimin and Abdul Mujib. 1993. Pemikiran Pendidikan Islam. Bandung: Trigenda.

Mulyana R. 2004. Mengartikulasikan Pendidikan Nilai. Bandung: Alfabeta.

Rahman, Nazarudin. 2009. Manajemen Pembelajaran ; Implementasi Konsep, Karakteristik dan Metodologi
Pendidikan Agama Islam di Sekolah Umum. Yogyakarta: Pustaka Felicha. Ramayulis. 2002. Ilmu Pendidikan Islam. Jakarta: Kalam Mulia.

Ramayulis. 2002. Metodologi Pengajaran Agama Islam. Jakarta: Kalam Mulia.

Tafsir, Ahmad. 2015. Ilmu Pendidikan Islam.. Bandung: PT Remaja Rosdakarya.

Tolchah, Mochammad. 2014. The Political Dimension of Indonesian Islamic Education in The Post-1998 Reform Period. (Jurnal Islam Indonesia, Vol. 8 Nomor 02. Desember 2014). 